\title{
Investigation into the Status Quo of "Dual-qualified" English Teachers on Basis of English Teaching for Specific Industry Jiao Peng*
}

Department of Information Engineering, Shandong Vocational College of Light Industry, Shandong Zibo 255300, China

116341059@qq.com

\author{
Keywords: Higher vocational education; Dual-qualified; English for specific industry
}

\begin{abstract}
In the higher vocational education, there are still no common ideas about "dual-qualified" teaching staffs. How to define "dual-qualified" English teachers and how to train and improve them, both of which are essential for the development of higher vocational education. The paper makes a case study of Shandong Vocational College of Light Industry and centers on some strategies for constructing "dual-qualified" English teachers in higher vocational colleges, hoping that it can propose the construction mechanism of English teachers.
\end{abstract}

\section{Introduction}

According to the Guidance of the Ministry of Education on Promoting the Coordinated Development of Secondary and Higher Vocational Education in 2011, it is not hard to see the development of China's vocational education must "promote the combination of business and education, carry out college-enterprise cooperation and work-integrated learning, accelerate professional and industrial jointing, teaching and production process jointing, qualifications and certificates jointing". Thus, it can be seen that the goal of higher vocational education is to train technical talents to adapt to the first-line needs of production, construction, management and service, which needs to be realized through the practical teaching of teachers. Therefore, the training of "dual-certified" talents inevitably requires "dual-qualified" teacher. It is not enough for them to just have rich theoretical knowledge, but also rich practical experience. Therefore, it is greatly necessary for the development and reform of vocational education.[1]

\section{What is Industrial English}

The definition of "Industrial English" has not yet been finalized. Some researchers think that "industrial English" is the so-called of "English for Special Purposes", which is based on demand analysis including target needs and learning needs. It is an English course associated with a specific profession or subject, which aims to meet learners' specific purpose and demand, such as legal English, medical English, fashion English, international finance English and so on.

The author thinks that there are differences between "industrial English" and "English for Special Purposes". Although there are similar contents between them, "industrial English" is not only related with a certain professional technical knowledge, but also related with various professional activities and characteristics of practitioners in such industry. Therefore, the development of "industrial English" puts forward new requirements for teachers.

\section{Requirements for "Dual-qualified" Teachers Under Industrial English Teaching Environment}

In order to cultivate a group of teachers who conform to the development of English education in higher vocational colleges, we should firstly ensure the current reform direction and course orientation. Professor Dailin LIU, the director of teaching committee of English major of higher vocational college, pointed out that the primary task of Basic Requirement is to reflect the professional features of English lesson, which can be reflected from the curriculum setting, curriculum organization, teaching and so on. The curriculum is based on basic English, business English, industrial English and ESP. Public English teacher should, therefore, transform into ESP 
teacher. A "dual-qualified" English teacher not only need solid skills of English, but also have to master the professional knowledge related to a specific profession or subject. They have to achieve related professional qualification certificate. Under the circumstance, they could have the competent to work in business line or already have been multi-technical talents with practical experience.[2-3]

\section{The Status Quo of "Dual-qualified" English Teachers --- A Case Study of Shandong Vocational College of Light Industry}

To make a study of Shandong Vocational College of Light Industry, 18 full-time English teachers have been investigated. The results are as follows:

Table 1 Survey Result of Shandong Vocational College of Light Industry

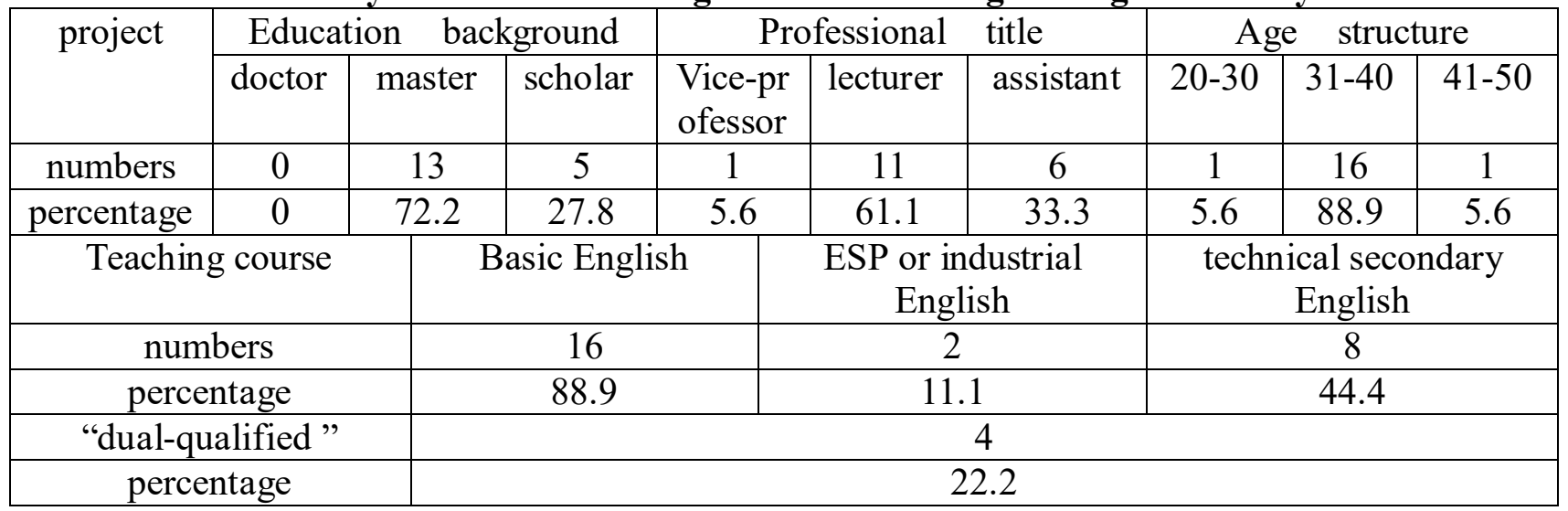

According to the above table, it can be seen that the construction of "dual-qualified " teacher in the college is too weak. Only 4 out of 18 full-time English teachers were identified as "dual-qualified ". but actually these four teachers just only obtained dual certificate, while practical ability of industry is weak. Thus, basic English and industrial English group construction system is not comprehensive. There are seven departments with 27 majors, but industrial English is only opened in few departments. Some professional teachers teach the lesson, but they are lack of English skills, otherwise, English teachers teach ESP course with poor professional and technical knowledge for specific major. Therefore, curriculum integration and promotion are difficult to proceed.

\section{Approach to Cultivate and Build the Group of" Dual-qualified" English Teacher}

As we know, the core of education reform is curriculum reform, and the core of curriculum reform is teaching, while the key of teaching is the teacher's concept, level and guidance. In the education system of modern vocational college, teacher requires to be both a teacher and a technical master with academic certificate and skill certificate. Combining with my own teaching practice, the author thinks the construction of "dual-qualified" English teachers can be strengthened through the following ways.

\section{To Weaken the Boundary and Integrate Basic English with Industrial English}

In order to integrate well industrial English into basic English teaching, vocational colleges should fix public English teachers to their professional groups, which is beneficial for them to improve their professional structure. Besides, they can both strengthen their English skills and expand knowledge fields according to the majors they teach. In Shandong Vocational College of Light Industry, the author mainly teaches college English and fashion English for students majored in garment. Considering foreign trade demand, the author pays attention to knowledge of apparel trade to let students be familiar with the professional term, trade process, etc. Students of Textile and Clothing Engineering Department are required to take fashion English course for two semesters in their sophomore year. It is found that when integrated fashion English into college English stage, students were more interested in opening their mouth and asking questions, and also the group 
cooperation was more tacit and the teaching effect was better.[4]

To Strengthen College-enterprise Cooperation and To Let Teachers Take Positions in

\section{Enterprises}

Vocational college can make use of the opportunity of "college-enterprise cooperation, work-integrated learning" to reasonably arrange public English teachers and professional teachers to work together in relevant enterprises. They need to understand professional technology and experience, improve their technical ability and practical teaching ability, combine the language teaching with the cultivation of professional technical ability, and strive to become a "dual-qualified" teacher.

To Encourage Teachers to Promote Skills Through Achieving Certificate

Public English teachers in higher vocational colleges usually take on heavy teaching tasks. Therefore, time is limited for them to practice in enterprises and participate in industrial training. Higher vocational education aims to cultivate applied talents, Thus, students have to get at least one vocational qualification certificate before their graduation. Therefore, it should be encouraged that English teachers also obtain relevant professional skills certificates, such as foreign language tour guide certificate, business English certificate, secretary certificate and logistician certificate. In the process of obtaining certificates, you can fully understand the industrial knowledge and skills to promote their knowledge structure, so as to integrate industrial knowledge into basic English.

\section{To Establish a Scientific and Completely "Dual-qualified" Teacher Mechanism}

It is necessary for higher vocational college to establish a set of scientific and completely guarantee mechanism in line with the actual condition of its education system. It is advocated to send excellent teachers by visiting scholar home and abroad, to make lectures, to encourage them for further study, to promote personal qualities such as professional qualification certificate, to mobilize teachers' enthusiasm, to motivate them to build up an overall atmosphere for working and doing research.

\section{Summary}

"Dual-qualified teacher" as a guide, its role is not only to change the professional development of English education, but also to use the language features to achieve the latest knowledge and technology in the professional fields. Teacher needs to timely convey the latest information to students, and guide them to realize development of their relevant major independently and keenly. The transition to "dual-qualified" teacher is a rare opportunity and also a huge challenge for English teachers. This transformation will also better cultivate students' English application ability.

\section{References}

[1] L. Jing: Education and Career, (2010) No.4,p.68-69

[2] L. Mu: Value Engineering, (2014) No.14,p.10-10

[3] B. Ying: Chinese Adult Education, (2015), No.9, p.27-27.

[4] H. Fen: Journal of Tianjin Vocational University, (2017), No.3, p.48-49 